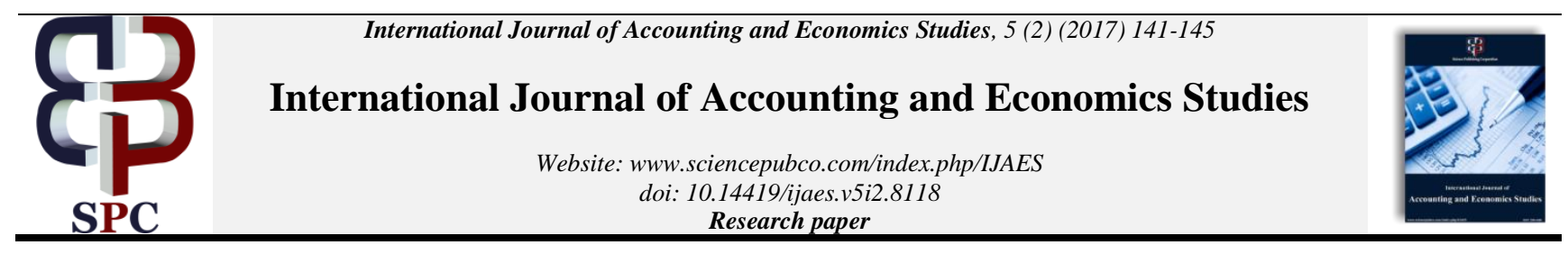

\title{
Lending rate and firms' investment decisions : Evidence from Ghana
}

\author{
Joseph Amo *, Hadrat M. Yusif \\ Department of Economics, Kwame Nkrumah University of Science and Technology, Kumasi, Ghana \\ *Corresponding author E-mail: amoscojoe@yahoo.com
}

\begin{abstract}
This paper has examined the impact of lending rate on firms' investment decision in Ghana. The Autoregressive Distributed Lag (ARDL) estimation framework was applied to time series data from 1980 to 2011 . We found that lending rate has significant negative impact on private investment in both short run and long run in Ghana. It was also found that real GDP has a significant direct impact on private investment in both the short run and the long run periods. Our findings have important implications for investment policy in Ghana.
\end{abstract}

Keywords: ARDL Cointegration; Ghana; Lending Rate; Private Investment.

\section{Introduction}

Financial institutions play a key role in the growth and development of the Ghanaian economy. Monetary Policy Committee of the Bank of Ghana report indicate that the financial service sector contributed $56.7 \%$ in total asset to gross domestic product (GDP) in 2008 while domestic credit provided by the banking sector as a percentage of GDP was $35.5 \%$ in 2015 . Thus, financial institutions improve resources allocation and investment opportunities as they link depositiors and borrowers ((WeiShong\&Kuo-Chung, 2006; Boachie et al., 2016). The borrowers comprise households, firms and the government and to obtain fund in this process they are charged interest by the financial institutions to cater for the transaction cost involved in the disbursement of the funds (Nalukenge, 2003).

Firms borrow to finance their investment in terms of plant and equipment, installation, expansion, raw materials and other investment activities. The activities of firms have significant positive impact on the Ghanaian economy in terms of increase in gross domestic product, job creation and thus improvement in the quality of life of the people. Business investment decisions in Ghana are mostly affected by the cost of borrowing (i.e., interest or lending rates) and other factors such as exchange rate volatilities (see e.g., Serven, 2003). This mean that when the cost of borrowing is high investment will be discouraged and thus lead to high unemployment and a reduction in the total spending and national income.

Therefore, in many developing countries like Jordan, Nigeria, Kenya etc researchers have investigated factors that influence private investment, especially interest rate. The effect of real interest rate on private investment spending was first captured in an investment equation by Jorgenson (1963). According to him changes in interest rates affect decisions about how to save and invest. Leahy (1963) reported that interest rate can have an important influence on the volume and disposition of savings as well as the volume and productivity of investment.

Consequently, in many countries both developed and developing, monetary authorities have maintained stable and relatively low rate of interest to ensure that investment activities are expanded and sustained. For example long term interest rate in U.S and Germany stood at $11.4 \%$ and $8.5 \%$ respectively in the year 1980 . On overage they have been around $1.9 \%$ and $0.3 \%$ respectively in 2016 and at about $0.3 \%$ in the Euro area. This has boosted investment and thus development in their economy. (ECB, 2016) In Ghana, as part of the effort to create the enabling environment for business activities to grow, the Central Bank ( Bank of Ghana) has focused on achieving low and stable inflation rate, stable exchange rate, and competitive interest rate in order to achieve macroeconomic stability (BOG, 2016 report; Alhassan et al., 2016). In 2008, the rate of inflation was $18.5 \%$ and this declined to $9.4 \%$ in August 2012. By July 2016 the inflation rate was 11.9 . As a consequence, the bank of Ghana also revised the prime rate downward from $18.5 \%$ in 2009 to $15 \%$ in December, 2012. By July, 2017 the prime rate was $21 \%$

Yet, universal banks lending rate in Ghana has persistently been increasing over the years. The lending rate was $25.02 \%$ in 2008 , then $32 \%$ in 2012 and $42.84 \%$ in 2016.

According to Eregha (2010) variation in interest rate plays a signifcant role in investment decisions in the economy.

However in Ghana there has hardly been any empirical study that has investigated the impact of lending rate on investment spending, especially the extent to which lending rates affect investment spending. What has been done so far mostly address the issue of determinants of investment, for example, Frimpong and Marbuah (2010), Asante (2000), Ibrahim (2000), and Islam and Wetzel (1991). Therefore, this study intends to empirically investigate the lending rate responsiveness of investment spending in Ghana using a co integration econometrics analysis, which so far has been ignored by the empirical literature done on Ghana.This study will be very useful to monetary authorities and policy makers in Ghana. 


\section{Previous empirical literature}

Many studies have been conducted on the lending rate and investment in many parts of the world. Majed and Ahmad (2010) studied the relationship between interest rate and investment in Jordan. They used Johansen cointegration methodology and the variables were real interest rate and income to study the relationship between investment and interest. Majed and Ahmad (2010) found that real interest rate was negatively associated with investment; an increase in the real interest rate by $1 \%$ reduces the investment level by $44 \%$. Income level however was found to exert a positive impact on investment.

Eregha (2010) conducted a study to find out changes in interest rate and investment determination in Nigeria. He applied instrumental variable technique to data for the period 1970-2002 and found that changes in interest rate have negative influence on investment decision in Nigeria.

Albu (2006) examined the trends in the interest rate, investment, and GDP growth relationship. The study also examined the relationship between interest rate and investment in Romania. The study found a strong inverse correlation between interest rate and investment in the Romanian economy and concluded that the behavior of the national economic system and interest rateinvestment relationship tend to converge to those demonstrated in the normal market economy.

Aysan et al (2005), in a study, analyzed the determinants of unsatisfying private investment growth in the Middle East and North Africa (MENA) throughout the 1980s and 1990s. Using panel data econometrics technique, they reported that the real interest rate appears to exert a negative effect on firm investment projects. Their conclusion was that the lack of economic reforms, and the deficiencies of the economic environment explain well the deficit in private investment and thus improvement of the debt burden, and a more stable economic activity would stimulate private firms' investment.

Badawi (2004) also employed annual data over the period 1968 to 1998 to examine the impact of macroeconomic policies on private investment in Sudan. Using co-integration vector auto regressive (VAR) and error correction techniques, the results indicated a significant negative impact of real interest rate on private investment in Sudan.

Hyder and Ahmad (2003) conducted a study about the slowdown in private investment in Pakistan using sample period from 1974 to 1999 . They found that higher real interest rate due to excessive borrowing cost is the major cause of low investment in Pakistan. They recommended bringing down the interest rate on borrowing as a way of enhancing private investment.

Ronge and Kimuyu (1997) using Ordinary Least Square (OLS) technique, investigated the determinants of private-sector investment for Kenya over the period 1964 to 1996 . The study found out that the availability of credit and foreign exchange has a direct impact on private investment. The study also observed a negative impact of exchange rate depreciation on investment Interest rate, however, was found to have insignificant impact on the level of private investment in Kenya.

Morisset (1991) employing the 3-stage least squares (3SLS) techniques over the period 1961 to 1982 , examined the effect of interest rate policies on private-sector investment spending in Argentina. The study revealed a very weak effect of changes in interest rates on private-sector investment, although the total impact was stronger on the quality of investment than on the quantity.

With regards to Ghana, Frimpong and Marbuah (2010) studied the determinants of private-sector investment in Ghana. They revealed that private investment is determined in the short-run by public investment, inflation, real interest rate, openness, real exchange rate and a regime of constitutional rule, while real output, inflation, external debt, real interest rate, openness and real exchange rate significantly influenced private investment response in the longrun.
Akpalu (2002) used annual time-series data from 1970 to 1994 to examine the determinants of private investment in Ghana. The study employed the Johansen multivariate test and Engle-Granger Two-Step approach and reported that there is a negative relationship between lending rate and private investment in both the short and long run. The study also revealed a significant direct relationship between private investment and real GDP in both the short and long run models. Inflation, however, was found to be insignificant in both short run and long run period.

Asante (2000) studied private investment behavior in Ghana using time-series data over the period 1970 to 1992 . The study used Ordinary Least Squares approach and found that growth rate of real credit to the private sector has a significant positive impact on investment with inflation having a significant negative impact.

Ibrahim (2000) in a similar study modelled the long-run determinants of private investment in Ghana using a dynamic optimization approach. Employing a Vector Error Correction Model within a restricted Vector Autoregressive (VAR) framework, a significant negative relationship was found between the real cost of investment and private investment in Ghana in the long-run.

\section{Materials and methods}

\subsection{Sources of Data}

We employed secondary data for the analysis. Annual time series data for the period $1980-2011$ were obtained from the World Bank (World Development Indicators) and the Bank of Ghana.

\subsection{Model specification}

Following Eregha (2010) and a study on the Sub-Sahara African country's investment determination model by Iyoha (2004) the study specifies the following model in order to assess the impact of lending rate on private investment in Ghana:

$\mathrm{RPI}_{\mathrm{t}}=\mathrm{B}_{0}+\mathrm{B}_{1} \mathrm{LR}_{\mathrm{t}}+\mathrm{B}_{2} \mathrm{INF}_{\mathrm{t}}+\mathrm{B}_{3} \mathrm{RGDP}_{\mathrm{t}}+\mathrm{B}_{4} \mathrm{REER}_{\mathrm{t}}+\mathrm{U}_{\mathrm{t}}$

Where;

$R P I_{t}$ is the Real Private Investment, $L_{t}$ is the Lending rate, $I N F_{t}$ is the inflation rate, $\mathrm{RGDP}_{t}$ is the income level, proxied by the real gross domestic product, $\mathrm{REER}_{\mathrm{t}}$ is the real exchange rate, $\mathrm{U}_{\mathrm{t}}$ is the error term and $\mathrm{t}$ is the time trend. The private investment model in equation (1) is specified in a log-linear form as:

$\operatorname{lnRPI} t=\beta_{0}+\beta_{1} \operatorname{lnLR}_{t}+\beta_{2} \operatorname{lnINF}_{\mathrm{t}}+\beta_{3} \operatorname{lnRGDP_{t}}+$

$\beta_{4} \operatorname{lnREER}_{\mathrm{t}}+\mathrm{U}_{\mathrm{t}}$

Where the $B_{i}$ represent the elasticity coefficients

The above equation (2) exhibits the long-run equilibrium relationship of the private investment model. The choice of the above linear model is due to the fact that the study sought to find the extent to which the changes in the lending rate, inflation rate, real GDP, and real exchange rate affect private investment decision. (i.e., elasticities of the variables). This situation is best depicted using log linear model, which seeks to find the percentage change in the dependent variable resulting from percentage changes in the independent variable.

Again, the use of log linear model can transform the values for all the variables to the same unit or level since the variables differ in sizes. Finally, the use of $\log$ transformation is necessary since it reduces the scale in which variables are measured, thereby reducing a tenfold difference between two values to a twofold difference, thus reducing the possibility of heteroskedasticity in the model (Gujarati, 1995). 


\subsection{Empirical estimation strategy}

\subsubsection{Augmented dickey-fuller (ADF) test}

The Augmented Dickey-Fuller (ADF) test was used to test the stationary status of the variables used in the private investment equation. The presence of unit root in the series indicates that the variable is non-stationary, hence the degree or order of integration is one or higher whereas the absence of unit root, implies otherwise.

\subsubsection{Cointegration test}

The ARDL cointegration technique also known as the Bound Test developed by Pesaran et al (2001) was used to investigate the existence or otherwise of long-run equilibrium relationships among the variables presented in the private investment model The choice of ARDL method of estimation is due to its numerous econometric advantages in comparison with other methods of cointegration. First, the ARDL cointegration procedure is relatively more efficient in small sample data sizes as it happens in this study. The total observation for the study is 22 , which is relatively small and thus suitable for ARDL procedure. The use of the ARDL estimation technique is applicable regardless of whether the regressors in the model are purely $\mathrm{I}(0)$, purely I (1) or mutually cointegrated. In order to apply the bounds test procedure for cointegration, the following conditional VECM is estimated to test the long-run relationship between private investment and the lending rate.

$\Delta \operatorname{lnPI} I_{t}=\beta_{0}+\theta_{1} \operatorname{lnPI}_{\mathrm{t}-1}+\theta_{2} \operatorname{lnLR} R_{\mathrm{t}-1}+\theta_{3} \operatorname{lnINF}_{\mathrm{t}-1}+$

$\theta_{4} \operatorname{lnRGDP} \mathrm{P}_{\mathrm{t}-1}+\theta_{5} \ln \mathrm{EXR}_{\mathrm{t}-1}+\sum_{\mathrm{i}=1}^{\mathrm{p}} \beta_{1 \mathrm{i}} \Delta \ln \mathrm{PI}_{\mathrm{t}-\mathrm{i}}+$

$\sum_{\mathrm{j}=1}^{\mathrm{q}} \beta_{2 \mathrm{j}} \Delta \ln \mathrm{LR}_{\mathrm{t}-\mathrm{j}}+\sum_{\mathrm{k}=1}^{\mathrm{q}} \beta_{3 \mathrm{k}} \Delta \ln \mathrm{INF}_{\mathrm{t}-\mathrm{k}}+$

$\sum_{\mathrm{l}=1}^{\mathrm{q}} \beta_{4 \mathrm{l}} \Delta \ln \operatorname{RGDP}_{\mathrm{t}-\mathrm{l}}+\sum_{\mathrm{m}=1}^{\mathrm{q}} \beta_{5 \mathrm{~m}} \Delta \ln \operatorname{REER}_{\mathrm{t}-\mathrm{m}}+\mu_{\mathrm{t}}$

Where, all variables are as previously defined and $\Delta$ is the first difference operator.

$\theta_{\mathrm{i}}$ are the long run multipliers and $\beta_{0}$ is the drift and $\mu_{\mathrm{t}}$ are the error terms.

In the second stage of the ARDL bounds approach, once cointegration is established the conditional ARDL ( $\mathrm{p}, \mathrm{q}_{1}, \mathrm{q}_{2}, \mathrm{q}_{3}$, $\mathrm{q}_{4}$,), the long-run model for RPIt can be estimated as:

$$
\begin{aligned}
& \operatorname{lnRPI} I_{\mathrm{t}}=\beta_{0}+\sum_{\mathrm{i}=1}^{\mathrm{p}} \theta_{1} \ln \mathrm{RPI}_{\mathrm{t}-\mathrm{i}}+\sum_{\mathrm{I}=0}^{\mathrm{q} 1} \theta_{2} \ln \mathrm{LR}_{\mathrm{T}-1}+ \\
& \sum_{\mathrm{i}=0}^{\mathrm{q} 2} \theta_{3} \ln \mathrm{INF}_{\mathrm{t}-1}+\sum_{\mathrm{i}=0}^{\mathrm{q} 3} \theta_{4} \ln \operatorname{RGDP}_{\mathrm{t}-\mathrm{l}}+\sum_{\mathrm{i}=0}^{\mathrm{q} 4} \theta_{4} \ln \operatorname{REER}_{\mathrm{t}-\mathrm{l}}+
\end{aligned}
$$$$
\mu_{\mathrm{t}}
$$

This process involves selecting the orders of the ARDL ( $p, q_{1}, q_{2}$, $\mathrm{q}_{3}, \mathrm{q}_{4}$,), model in the five variables using Schwartz Bayesian Information Criterion.

The third step in the ARDL bound approach involves estimating an Error Correction Model (ECM) to capture the short-run dynamics of the system. The ECM generally provides the means of reconciling the short-run behaviour of an economic variable with its long-run behaviour.

The error correction version of ARDL model pertaining to the long run estimates is specified as follows:

$$
\begin{aligned}
& \Delta \operatorname{lnRPI} I_{\mathrm{t}}=\gamma+\sum_{\mathrm{i}=1}^{\mathrm{p}} \beta_{1 \mathrm{i}} \Delta \ln \mathrm{RPI}_{\mathrm{t}-\mathrm{i}}+\sum_{\mathrm{j}=1}^{\mathrm{q}} \beta_{2 \mathrm{j}} \Delta \ln \mathrm{LR}_{\mathrm{t}-\mathrm{j}}+ \\
& \sum_{\mathrm{k}=1}^{\mathrm{q}} \beta_{3 \mathrm{k}} \Delta \ln \mathrm{INF}_{\mathrm{t}-\mathrm{k}}+\sum_{\mathrm{l}=1}^{\mathrm{q}} \beta_{41} \Delta \ln \operatorname{RGDP}_{\mathrm{t}-\mathrm{l}}+ \\
& \sum_{\mathrm{m}=1}^{\mathrm{q}} \beta_{5 \mathrm{~m}} \Delta \ln \operatorname{REER}_{\mathrm{t}-\mathrm{m}}+\rho \mathrm{ECM}_{\mathrm{t}-1}+\mu_{\mathrm{t}}
\end{aligned}
$$

From equation (5), $\beta \mathrm{i}$ represent the short-run dynamics coefficients of the model's convergence to equilibrium. $\mathrm{ECM}_{\mathrm{t}-1}$ is the Error Correction Model and $\rho$ which is the coefficient of the Error Correction Model, represents the speed of adjustment for short run divergence to the long run equilibrium following a shock to the system.

\section{Results and discussion}

\subsection{Results of the unit root tests}

The results of the unit root test are presented in Table 1 below.

\begin{tabular}{|c|c|c|c|c|c|}
\hline Variables & LAGS & \multicolumn{2}{|l|}{ Level } & \multicolumn{2}{|c|}{ First Difference } \\
\hline & & Constant & $\begin{array}{l}\text { Constant + } \\
\text { Trend }\end{array}$ & Constant & $\begin{array}{l}\text { Constant + } \\
\text { Trend }\end{array}$ \\
\hline LNRPI & 1 & $\begin{array}{l}0.393 \\
(0.8985)\end{array}$ & $\begin{array}{l}-2.545 \\
(0.3043)\end{array}$ & $\begin{array}{l}- \\
5.306^{* * * *} \\
(0.0001)\end{array}$ & $\begin{array}{l}-5.173 * * * \\
(0.0012)\end{array}$ \\
\hline LNINF & 1 & $\begin{array}{l}- \\
3.552 * * \\
(0.0130)\end{array}$ & $\begin{array}{l}-5.109 * * \\
(0.013)\end{array}$ & $\begin{array}{l}- \\
8.449 * * * \\
(0.000)\end{array}$ & $\begin{array}{l}-4.865^{* * * *} \\
(0.0034)\end{array}$ \\
\hline LNLR & 1 & $\begin{array}{l}-2.288 \\
(0.1822)\end{array}$ & $\begin{array}{l}-2.006 \\
(0.5751)\end{array}$ & $\begin{array}{l}- \\
7.631^{* * *} * \\
(0.0000)\end{array}$ & $\begin{array}{l}-7.606^{* * * *} \\
(0.0000)\end{array}$ \\
\hline LNREER & 1 & $\begin{array}{l}-1.526 \\
(0.5076)\end{array}$ & $\begin{array}{l}-1.715 \\
(0.7203)\end{array}$ & $\begin{array}{l}5.703 * * * \\
(0.0001)\end{array}$ & $\begin{array}{l}-5.904 * * * \\
(0.0002)\end{array}$ \\
\hline LNRGDP & 1 & $\begin{array}{l}1.786 \\
(0.9995)\end{array}$ & $\begin{array}{l}-1.535 \\
(0.7949)\end{array}$ & $\begin{array}{l}- \\
4.943 * * * \\
(0.0004)\end{array}$ & $\begin{array}{l}-5.233 * * * \\
(0.0010)\end{array}$ \\
\hline
\end{tabular}
The test regression was conducted using the levels and the first differences of the variables in the investment equation for a constant, as well as a constant and trend

Table 1: ADF Test for Unit Root

Table1 presents the unit root test results and with exception of INF that achieved stationarity at the levels, all the other variables achieved stationarity after first differencing. Since most of the variables are I (1), implying the mixed orders of integration of the series the use of the ARDL model is justified as opposed to any of the alternative co -integration approaches that are valid only when the series are integrated of the same order.

\subsection{ARDL bounds test for cointegration}

The results of the bound testing approach for co -integration are reported in Table 2

Table 2: ARDL Cointegration Test Results

\begin{tabular}{lllll}
\hline F-stat. & $95 \% \mathrm{I}(0)$ & $95 \% \mathrm{I}(1)$ & $90 \% \mathrm{I}(0)$ & $90 \% \mathrm{I}(1)$ \\
\hline 5.5792 & 3.3269 & 4.7302 & 2.7395 & 3.9516 \\
& RPI = F(LR, INF, RGDP, REER) = 5.5792**. \\
\hline
\end{tabular}

** denotes significance at $5 \%$ level. Decision rule: If the statistic lies between the bounds, the test is inconclusive. If it is above the upper bound, the null hypothesis of no level effect is rejected. If it is below the lower bound, the null hypothesis of no level effect cannot be rejected.

Table 2 shows that the computed F-value of 5.5792 is higher than the upper bound critical value of 4.7302 at $5 \%$ level of significance. This implies that the null hypothesis of no co-integration between the variable is rejected. Thus, there is evidence of cointegration (long run relationships) amongst the variables in the private investment function.

\subsection{Analysis of estimated long run results}

Table 3 presents the long run results of the private investment model, estimated from the ARDL $(1,0,0,1,0))$ model based on the Schwarz Bayesian Criterion (SBC) using Microfit 5.0 Time series Econometrics software. 
Table 3: Long Run Coefficients Using the ARDL Approach.

\begin{tabular}{lllll}
\hline Regressor & Coeff. & Std. Error & T-ratio & Prob. \\
\hline C & -3.1804 & 2.5518 & -1.2463 & 0.224 \\
LNLR & -0.62892 & 0.24144 & $-2.6049 * *$ & 0.015 \\
LNINF & -0.016532 & 0.083424 & -0.19817 & 0.845 \\
LNRGDP & 1.0772 & 0.094647 & $11.3815^{* * *}$ & 0.000 \\
LNREER & -0.41368 & 0.098519 & $-4.1990^{* * *}$ & 0.000 \\
** and *** denote significance at 5\% and 1\% levels respectively \\
ARDL (1,0,0,1,0) selected based on Schwarz Bayesian Criterion \\
Dependent Variable: LNRPI \\
\hline
\end{tabular}

The regression estimates in Table 3 show that the coefficients of the private investment model have their expected signs but not all are statistically significant. The coefficient of lending rate variable is negative and statistically significant at $5 \%$ level. This confirms our a priori expectation that lending rate is negatively correlated with private investment in Ghana. If lending rate increases by $1 \%$, real private investment will fall by 0.63 percent. This is consistent with interest rate theory. Our findings confirms Majed and Ahmed (2010)'s study in Jordan. It is also consistent with the findings of Arysan (2005) and Albu (2006) who also found a similar long run negative relationship between investment and interest rate in the Romania.

We included real GDP, inflation and real exchange rate in the equation. From Table 3, the coefficient of the real GDP is positive and statistically significant at $1 \%$ level. This suggests that real GDP has positive effect on investment. Frimpong and Marboah (2010), Ibrahim (2000), Asante (2000), and Akpalu (2002) have reported similar findings. Also, the coefficient of inflation rate is negative and insignificant. The rate of inflation tends to raise the cost of borrowing and thus lowers the rate of capital investment. This discourages long-term lending by financial intermediaries and this tends to reduce investment rates. This result is consistent with most empirical findings such as Khan and Senhadji (2000) and Temple (1999).

Real exchange rate has negative and significant coefficient. This implies that the depreciation of the cedi by $1 \%$ will cause private investment to fall by 0.42 percent. Ronge and Kimuyu (1997) also found similar result where exchange rate depreciation negatively affected private investment in Kenya.

\subsection{Results of the short-run error private investment equation}

The results of the short-run dynamic coefficients associated with the long run relationships are presented in table 4 . The results are similar to the long run results.

Table 4: Estimated Short- Run Error Correction Model using the ARDL Approach

\begin{tabular}{lllll}
\hline Regressor & Coeff. & Std. Error & T-Ratio & Prob. \\
\hline C & -2.3896 & 2.0885 & 4.3239 & 0.000 \\
D(LnLR) & -0.47255 & 0.21209 & $-2.2280^{* * *}$ & 0.035 \\
D(LnINF) & -0.12422 & 0.62709 & -.19810 & 0.845 \\
D(LnRGDP & 0.8093 & 0.16687 & $4.8505 * * *$ & 0.000 \\
D(LnREER) & -0.31083 & 0.71887 & -4.3239 & 0.263 \\
ECM(-1) & -0.75137 & 0.12133 & $-6.1927 * * *$ & 0.000 \\
ECM = LNRPI + $0.62892 L N L R+0.016532 L N I N F-1.0772 L N R G D P+$
\end{tabular}

$0.41368 \mathrm{LNREER}+3.1804 \mathrm{C}$

\begin{tabular}{|c|c|c|c|}
\hline \multicolumn{4}{|c|}{ Model Summary } \\
\hline R-Square & 0.63672 & R-Bar-Square & 0.58083 \\
\hline $\begin{array}{l}\text { Mean of De- } \\
\text { pendent Vari- } \\
\text { able }\end{array}$ & 0.10171 & F-Stat.F $(4,26)$ & $11.3925[0.000]$ \\
\hline $\begin{array}{l}\text { Residual Sum } \\
\text { of Squares }\end{array}$ & 0.69187 & $\begin{array}{l}\text { S.D of De- } \\
\text { pendent Varia- } \\
\text { ble }\end{array}$ & 0.25196 \\
\hline $\begin{array}{l}\text { Akaike Info. } \\
\text { Criterion }\end{array}$ & 9.9494 & $\begin{array}{l}\text { Equation Log - } \\
\text { likelihood } \\
\text { Schwarz }\end{array}$ & 14.9494 \\
\hline DW-Statistic & 1.9719 & $\begin{array}{l}\text { Bayesian Crite- } \\
\text { rion }\end{array}$ & 6.3644 \\
\hline
\end{tabular}

$* *$ and $* * *$ denote significance at $5 \%$ and $1 \%$ levels respectively

ARDL $(1,0,0,1,0)$ selected based on Schwarz Bayesian Criterion.

Dependent variable is D(LNRPI)
Consistent with the long-run results, the coefficient of lending rate has the theorized negative impact on private investment in the short-run and is statistically significant at one percent error levels. The results suggest that, in the short run, an increase in lending rate by $1 \%$ will reduce the level of private investment by 0.47 percent. Hence the results suggest that, the impact of increasing lending rate have a greater negative effect on private investment in the long run than in the short run.

The inflation rate has an adverse impact on private investment in the short run. The coefficient of inflation $(-0.12422)$ in the shortrun is negative but is not statistically significant. The result therefore implies that, in the short run, an increase in inflation by $1 \%$ will reduce the level of private investment by 0.124 percent. Hence both short-run and long-run results suggest that inflation has detrimental effect on private investment. This is consistent with findings of Asante (2000) who found the rate of inflation to have impacted adversely on private investment in Ghana.

The coefficient of the real GDP variable is positive and also significant at $1 \%$ level. The short run result is consistent with the long run results emphasizing the important role that real GDP plays in promoting private investment and economic growth in Ghana.

The coefficient of real exchange rate has the expected negative impact on private investment as it was, in the long run model. However, in the case of the short -run model, the impact is not statistically significant even at $10 \%$ error level. However, it negative effect implies that exchange rate depreciation will have a detrimental effect on private investment in Ghana. Thus, private investment will decrease by 0.31 percent should the cedi depreciate by 1 percent. This justifies the relative importance of exchange rate movement on private investment in Ghana

Finally, the error correction term coefficient (-0.75137) which measures the speed of adjustment to restore equilibrium following shock in the dynamic model has the expected negative sign and is statistically significant at 1 percent. The coefficient of the error correction term, therefore, measures the speed at which Private investment adjusts to changes in lending rate, inflation, real GDP and real exchange rate.

The error correction model passed the diagnostic tests. The F-statistics value of 11.3925 with its P-value of 0.000 is a clear indication that the overall regression is highly statistically significant. The R-Squared and the R-Bar-Squared values of 0.63672 and 0.58083 respectively implies that the model has high explanatory power and that about $63 \%$ of the variation in private investment is explained by variations in the independent variables (lending rate, inflation, real GDP and real exchange rate) DW-statistic of 1.9719 indicates that there is no strong serial correlation in the residuals.

\section{Conclusion and Policy Implications}

This paper has measured the effect of lending rate on investment in Ghana. We also controlled for real GDP, inflation and real exchange rate. ARDL econometric estimation technique was employed. The study revealed that the variable of interest i.e. lending rate, has a negative influence on investment in Ghana. Regarding the control variables, we found that inflation is negatively associated with private investment in both short and long run periods.

The study also showed that real GDP has a positive influence on private investment in both the short run and the long run periods. The study found that, in both the short run and long run, movement in real exchange rate has no significant impact on private investment in Ghana but significantly explains the level of private investment in the long run. This can be explained by the fact that the economy of Ghana is import dependent and hence as the economy expands there will be increase in demand for import such as machinery and other raw materials needed for investment purposes. 
In view of the findings of the study, the Monetary Policy Committee of the Bank of Ghana institute measures and policies towards bringing the lending rate down in order to increase investment. Controlling other key factors that influence the setting of the lending rate of financial institutions such as operational cost, default rate, the rate of tax, and treasury bill rate could go a long way to reduce high lending rate in Ghana. Further, the bank of Ghana must place a legal cap on lending rate in Ghana and strictly enforce the financial institution to stay within the limit.

\section{References}

[1] Akpalu, W., (2002): "Modelling Private Investment in Ghana: An Empirical Time Series Econometrics Investigation (1970-1994)," The Oguaa Journal of Social Sciences, Vol. 4, Faculty of Social Sciences, University of Cape Coast.

[2] Albu, L (2006), "Trends in the Interest Rate-Investment-GDP growth relationship", Romanian J. Econ. Forecast, 3:5-13.

[3] Alhassan, M., Yusif, H., and Buabeng, E. (2016).Inflation targeting and economic growth in Ghana: An empirical Investigation. Ghanaian Journal of Economics, 4:158-177

[4] Asante, Y., (2000): "Determinants of Private Investment Behaviour," AERC Research Paper No. 100, Nairobi: AERC.

[5] Aysan, A., Gaobo, P. and Marie-Ange V. (2005) "How to Boos Private Investment in the MENA Countries: The Role of Economic Reforms", Topics in Middle Eastern and North African Economics, MEEA, Online Journal, (VII): 1-15

[6] .Badawi, A., (2004): "Private Capital Formation and Macroeconomic Policies in Sudan: Application of a Simple Cointegrated Vector Autoregressive Model," Department of Economics, University of Khartoum.

[7] Boachie, MK, Mensah, IO, Frimpng AO, and Ruzima, M. (2016) Interest Rate, liquidity and stock market performance in Ghana, International journal of Accounting and Economics Studies, 4(1):4651.

[8] Eregha, P. B. (2010), "Interest Rate Variation and Investment Determination in Nigeria', Medwell Journals 2010

[9] Frimpong M. J and Marbuah G. (2010)"The Determinants of Private Sector Investment in Ghana: An ARDL Approach" European Journal of Social Sciences - Volume 15, Number 2(2010)

[10] Goldberg, L.S. (1993). "Exchange Rates and Investment in the United States Industry."Review of Economics and Statistics 125: 575-88. https://doi.org/10.2307/2110011.

[11] Gujarati, D.N (1995): Basic Econometrics (3 ${ }^{\text {rd }}$ eds), New York McGraw-Hillhttp://www.luc.edu/orgs/meea/volume7/Aysan.pdf. (Accessed May 10, 2010).

[12] Hyder, K. and Ahmad, G.M. (2003). Why Private Investment in Pakistan has collapsed and how can it be restored? [Online] Available:http://economics.cal/2003/papers/0454.pdf

[13] Ibrahim, S.B., (2000): "Modelling the Determinants of Private Investment in Ghana," The African Finance Journal, Vol. 2, Part 2. pp 15-39.Institution, Washington DC.

[14] Islam, R., and D.L. Wetzel, (1991): "The Macroeconomics of Public Sector Deficits: The Case of Ghana," Country Economics Department Working Papers, No. 672, World Bank.

[15] Iyoha, M.A.,(2004), “Applied Econometrics", Mindex Publishing, Benin, PP: 37-43

[16] Jorgenson, D (1963): "Capital theory and investment behavior", The American Economic Review, 53 (2), 247-259

[17] Khan, M.S and A.S. Senhadji (2000). Threshold Effects in the Relationship between Inflation and Growth. IMF Working Paper, $\mathrm{WP} / 00 / 110$

[18] Leahy, J (1993) "Investment in competitive equilibrium: The optimality of myopic behavior". O.J Econ., 103:1105-1113 https://doi.org/10.2307/2118461.

[19] Majed B and Ahmad I. M (2010) "The Impact of Interest Rate on Investment in Jordan: Acointegration Analysis”Econ. \& Adm., Vol 24 No. 1, pp: 199-209 (2010 A.D./1431 A.H.)

[20] Morisset, J. 1991: "Does Financial Liberalization Really Improve Private Investment in Developing Countries?," Working Paper Series 717, Debt and International Finance, International Economics Department, The World Bank, Washington: DC

[21] Nalukenge, I.K. (2003) "Impact of Lending Relationships on Transaction Costs Incurred by Financial Intermediaries

[22] Pesaran, M. H., Shin, Y. C., and Smith, R., (2001). Bound Testing Approaches to the Analysis of Level Relationships. Journal of Applied Econometrics, 16, 289-326. https://doi.org/10.1002/jae.616.
[23] Ronge, E. E., and P.K. Kimuyu, (1997): "Private Investment in Kenya: Trends, Composition and Determinants," IPAR. Mimeograph

[24] Servén, Luis (2003) Real-Exchange-Rate Uncertainty and Private Investment in LDCS, The Review of Economics and Statistics, Vol. 85, No. 1 (Feb., 2003), pp. 212-218 https://doi.org/10.1162/rest.2003.85.1.212.

[25] Wei-Shong, L.N and Kuo-Chung, M.A. (2006). "The internal performance measures of bank lending: a value-added approach". Emerald Group Publishing Ltd. Vol. 13, No.3, 2006, pp.272-289. 